\title{
Genetic Diversity and Relationships among Local Olive (Olea europeaea L.) Genotypes from Gaziantep Province and Notable Cultivars in Turkey, Based on SSR Markers
}

\author{
Ebru SAKAR ${ }^{1 *}$, Hulya UNVER ${ }^{2}$, Mehmet ULAS ${ }^{3}$, \\ Biljana LAZOVIC ${ }^{4}$, Sezai ERCISLI ${ }^{5}$
}

\author{
${ }^{1}$ Harran University, Agricultural Faculty, Department of Horticulture, Sanliurfa, Turkey; ebru.sakar09@gmail.com (*corresponding author) \\ ${ }^{2}$ Duzce University, Faculty of Agriculture and Natural Science,Duzce, Turkey; bulyaunver@hotmail.com \\ ${ }^{3}$ Bornova Olive Research Institute, Izmir, Turkey; mculas@gmail.com \\ ${ }^{4}$ Centre for Subtropical Fruits, Bar; Biotechnical faculty, Podgorica, Montenegro; biljanal@t-com.me \\ ${ }_{5}^{5}$ Atatürk University, Agricultural Faculty, Department of Horticulture, Sanliurfa, Turkey; sercisli@gmail.com
}

\begin{abstract}
Olive and olive oil have a prominent place in the cultures of the countries within the Mediterranean basin including Turkey. The genetic relationships among 30 olive (Olea europaea L.) genotypes sampled from Gaziantep province in Turkey were examined using 10 simple sequence repeat (SSR) markers (DCA9, DCA11, DCA15, DCA18UDO4, UDO9, UDO11, UDO12, UDO22, UDO24). Also, three well known Turkish and one foreign olive cultivar were also included within the SSR analysis. The number of alleles per locus of the SSR markers ranged from 5 (DCA15, UDO9) to 14 (DCA9) (average 7.9), for a total of 79 alleles. Similarity coefficients were calculated on the basis of 79 amplified bands. A dendrogram was created according to the 10 SSR markers by the unweighted pair-group method. The banding patterns obtained from the SSR primers allowed all of the genotypes/cultivars to be distinguished. According to the dendrogram, the 33 olive genotypes and cultivars were clustered into five main clusters. The most closely related genotypes were 'Oguzeli 3' and 'Yavuzeli 1' with 0.80 similarity ratio. The most genetically divergent cultivars were 'Yavuzeli 6' and 'Kilis Yaglik' (0.30), 'Yavuzeli 6' and 'Saurani' (0.20), 'Nizip 7' and 'Yavuzeli 4' (0.15), 'Islahiye 5' and 'Nizip Yaglik' (0.10). In conclusion, SSR analysis can be an efficient method for olive genotypes and cultivar identification and can offer valuable informative data to identify olive genotypes and cultivars grown in Turkey.
\end{abstract}

Keywords: molecular markers, olive, Simple Sequence Repeat Marker

\section{Introduction}

The Mediterranean basin has very suitable environmental conditions for olive (Olea europaea L.) growing and the Mediterranean basin countries accounted for approximately $97 \%$ of the world's olive production currently accounting more than 800 million of olive trees (FAO, 2014). In main olive producer countries, more than $90 \%$ of olive fruits are used for oil production and the rest of the production is consumed as table olives; it is estimated that more than 2.500.000 tons of olive oil are produced annually throughout the world (IOOC, 2015).

The olive is one of the most widely cultivated and economically important fruit crop for several Mediterranean countries, mainly for Spain, Italy, Greece, Turkey and Portugal (Ercisli et al., 2011). These Mediterranean countries had cultivated (Olea europaea subsp. europaea var. sativa) and wild olive trees (Olea europaea subsp.europaea var.sylvestris) (Boskou, 2009). It is believed that cultivated varieties of Olea europaea supsp. europaea var. sativa were derived from the wild type Olea europaea subsp. europaea var. sylvestris in the Mediterranean region and then were spread throughout the world (Sesli and Yegenoglu, 2010). This crop is also having an increasing economic interest beyond Mediterranean basin countries, such as Argentina, Australia, Brazil, Chile, South Africa and USA. The olive tree has been naturalized in several regions of America, where it is used for the olive industry.

The number of olive oil consumers has been increasing, especially since recent evidence suggests health and nutritional benefits of virgin olive oil (Poljuha et al., 2008). Virgin olive oil (VOO) is a source of at least 30 antioxidant phenolic 
558

compounds and 100 aromatic compounds that contribute to its bitter taste and aroma; also, it is the only oil that can be eaten without refining. Olive oil is ranked sixth in level of world cooking oil production. (Navero et al., 2000; Besnard et al., 2007; Kole, 2011; Aparicio and Harwood, 2013).

Different techniques have been used to characterize olive diversity. Morphological criteria such as leaf, fruit, seed and growth behaviour have been used to evaluate olive diversity, as well as to determine the origin of olive trees. An evaluation of phenotypic diversity was used to discriminate olive cultivars with distinct morphological and pomological characters (Ipek et al., 2012). There are many systematic identification procedures that have been developed to help identify genetic diversity in olive trees. These include chemical (fatty acids and oil content) and phenological parameters (dates of first leaves, fruits and flowers) as reported by Lumaret et al. (2004) and Taamalli et al. (2006). Isozyme analysis has also been used to analyze the genetic diversity in cultivated and wild type olives because morphological traits have in general not been able to clearly differentiate between closely related cultivars (Kole, 2011). As well known, almost all morphological and biochemical characters are controlled by minor polygenic traits and are easily affected by environmental factors. Farming practices, age and developmental stages of plants affect morphological and biochemical characters as well (Khakwani $e t$ al., 2005; Kaczmarka et al., 2015; Nemli et al., 2015).

The identification of olive cultivars and their area of origin are very important in order to expand cultivation of those commercial varieties with superior yields, that are best adapted to specific local environmental conditions (Sarri et al., 2006; Poljuha et al., 2008). The presence of synonymous clones and mislabelling has been reported in olive orchards. Researchers have failed to accurately evaluate these two forms by using morphological studies due to the similarities in phenotypes (Belaj et al., 2003) and environmental influence (phenotypic plasticity) over specific traits.

DNA-based markers are more reliable for cultivar and subspecies identification than phenotypic traits, since they are not influenced by environmental conditions (Sesli and Yegenoglu, 2010). Molecular markers have been developed for olives in order to facilitate accurate cultivar identification (Belaj et al., 2003). This enables clear identification of genetic polymorphism within and among olive cultivars. Previous research clearly indicated that the SSR technique was more appropriate than AFLPs and RAPDs for polymorphic detection, which more clearly distinguishes among closely related cultivars (Belaj et al., 2003; Montemurro et al., 2008; Muzzalupo et al., 2014; Abdessemed et al., 2015). In olive cultivar identification, microsatellites have a lot of advantages compared to the other PCR (Polymerase Chain Reaction) based molecular markers techniques due to co-dominant and easily reproducible characteristics, frequent and random distribution, thus allowing a wide coverage of the genome. Microsatellites detect a high level of variation and reduce the number of markers required to distinguish between genotypes in olive (Kole, 2011).

In light of the general lack of detailed information about genetic diversity and relationships in native olive cultivars from Turkey, the present study evaluated genetic diversity and relationships among the most important olive genetic resources in Turkey.

\section{Materials and Methods}

\section{Plantmaterial}

In the study there were used thirty genotypes widely grown within different parts of Gaziantep; one well-known foreign and three Turkish reference olive cultivars were added to the study in order to have valuable comparison data (Table 1). For this reason, leaf samples of all thirty olive genotypes and the four cultivars used in the hereby study were collected in Turkey and finally a total of thirty-four olive genotypes were included in SSR analysis.

\section{DNA extraction}

Genomic DNA was extracted from young leaf tissue using the Wizard ${ }^{\circ}$ Genomic DNA Purification Kit (Promega, Madison, WI) according to the instructions provided by the manufacturer. Subsequently, a RNAse treatment was performed on the eluted DNA samples. Purity and concentration of the DNA were checked both on $1 \%(\mathrm{w} / \mathrm{v})$ agarose gels and by NanoDrop ${ }^{\circ} \mathrm{ND}-1000$ spectrophotometer.

\section{SSR analysis}

Ten widely used SSR loci (DCA15, DCA18, UDO12, UDO24, UDO4, UDO9, DCA11, DCA9, UDO22, UDO 11) were used in Polymerase Chain Reaction (PCR) studies. PCR was conducted in a volume of $10 \mu \mathrm{L}$ and contained $15 \mathrm{ng}$ genomic DNA, 5 pmol of each primer, $0.5 \mathrm{mM}$ dNTP, 0.5 unit GoTaq DNA polymerase (Promega), $1.5 \mathrm{mM} \mathrm{MgCl}_{2}$ and $2 \mu \mathrm{L} 5 \mathrm{X}$ buffer. The forward primers were labelled with Well RED fluorescent dyes D2 (black), D3 (green) and D4 (blue) (Proligo, France). Reactions without DNA were included as negative controls. PCR amplification was performed by using the Biometra ${ }^{\circ}$ PCR System. The amplification conditions consisted of an initial denaturation step of $3 \mathrm{~min}$ at $94^{\circ} \mathrm{C}$, followed by 35 cycles of $1 \mathrm{~min}$ at $94^{\circ} \mathrm{C}, 1 \mathrm{~min}$ at $52-56^{\circ} \mathrm{C}$ and $2 \mathrm{~min}$ at $72^{\circ} \mathrm{C}$, with a final extension at $72^{\circ} \mathrm{C}$ for $10 \mathrm{~min}$. The PCR products were first separated on a $3 \%(w / v)$ agarose gel run at $80 \mathrm{~V}$ for $2 \mathrm{hrs}$. The gel was then stained with ethidium bromide at a concentration of $10 \mathrm{mg} / \mathrm{mL}$. A DNA ladder $(100$ bp) (Promega) was used for the approximate quantification of the bands. The amplification products were visualized under UV light and their sizes were estimated relative to the DNA ladder. For further determination of polymorphisms, the PCR products were run on CEQTM 8800 XL Capillary Genetic Analysis System (Beckman Coulter, Fullerton, CA). The analyses were repeated at least twice to ensure reproducibility of the results. Allele sizes were determined for each SSR locus using the Beckman CEQTM Fragment Analysis software. In each run, foreign reference cultivars were included.

\section{Genetic analysis}

The genetic analysis program "IDENTITY" 1.0 [9] was used according to Paetkauet et al. (1995) for the calculation of number of alleles, allele frequency, expected and observed heterozygosity, estimated frequency of null alleles, and probability to identity per locus. Genetic dissimilarity was determined by the program "MICROSAT" (version 1.5) (Minch et al., 1995) using proportion of shared alleles, which was calculated by using "ps (option 1- (ps))", as described by Bowcock et al. (1994). The results were then converted to a similarity matrix, and a dendrogram was constructed with the 
Table 1. Utilization, origin and growing areas of thirty olive genotypes and four cultivars

\begin{tabular}{|c|c|c|}
\hline Genotype & Utilization & Origin and growing area \\
\hline 'Islahiye 1' & Oil & Mediterranean \\
\hline 'Islahiye 2' & Oil & Mediterranean \\
\hline 'Islahiye 3 & Oil & Mediterranean \\
\hline 'Islahiye 4' & Table and Oil & Mediterranean \\
\hline 'Islahiye 5' & Table and Oil & Mediterranean \\
\hline 'Oğuzeli 1' & Table and Oil & Mediterranean \\
\hline ‘Oğuzeli 2’ & Oil & Mediterranean, \\
\hline 'Oğuzeli 3' & Oil & Mediterranean \\
\hline 'Oğuzeli 4' & Oil & Mediterranean \\
\hline 'Oğuzeli 5’ & Oil & Mediterranean \\
\hline 'Karkamış 1' & Table and Oil & Mediterranean \\
\hline 'Karkamış 2’ & Table and Oil & Mediterranean \\
\hline ‘Karkamış 3’ & Oil & Mediterranean \\
\hline 'Karkamış 4' & Oil & Mediterranean \\
\hline 'Karkamış 5’ & Oil & Mediterranean \\
\hline 'Nizip 1' & Oil & Mediterranean \\
\hline 'Nizip 2' & Oil & Mediterranean \\
\hline 'Nizip 3' & Oil & Mediterranean \\
\hline 'Nizip 4' & Table and Oil & Mediterranean \\
\hline 'Nizip 5' & Table and Oil & Mediterranean \\
\hline 'Nizip 6' & Table and Oil & Mediterranean \\
\hline 'Nizip 7’ & Table and Oil & Mediterranean \\
\hline 'Yavuzeli 1' & Oil & Mediterranean \\
\hline 'Yavuzeli 2' & Table and Oil & Mediterranean \\
\hline 'Yavuzeli 3' & Oil & Mediterranean \\
\hline Yavuzeli 4' & Oil & Mediterranean \\
\hline 'Yavuzeli 5' & Oil & Mediterranean \\
\hline 'Yavuzeli 6' & Green-Table & Mediterranean \\
\hline 'Yavuzeli 7’ & Table and Oil & Mediterranean \\
\hline 'Yavuzeli 8' & Table and Oil & Mediterranean \\
\hline cv. 'Sarı ulak' & Green, Black-Table & TR, Mediterranean \\
\hline cv. 'Nizip Yağlık' & Oil & TR, Southern Anatolia \\
\hline cv. 'Kilis Yağlık' & Oil & TR, Southern Anatolia \\
\hline cv. 'Saurani' & Oil & Syria \\
\hline
\end{tabular}

\section{TR: Turkey}

UPGMA method (Sneath and Sokal, 1973) using the software NTSYS-pc (Numerical Taxonomy and Multiware Analysis System, version 2.0) (Rohlf, 1988).

\section{Results and Discussion}

A matrix of 10 SSR primers for the 34 olive individuals (Table 1) was used to evaluate the genetic relationships among local genotypes, national and new introduced cultivars. Using DNA samples isolated from the 34 olive genotypes and cultivars as templates, polymorphic DNA fragments were amplified from all 10 highly polymorphic simple sequence repeat (SSR) primer pairs and the results of molecular analysis of the 34 genotypes and cultivars generated by SSR primer pairs are summarized in Table 2 . Ten SSR loci were also used aiming to identify if duplicate olive cultivar samples were present in the dataset.

A total of 79 polymorphic alleles with the average alleles per locus of 7.9 were detected within the 10 SSR loci. The maximum alleles were observed at the loci of DCA9 as 14, while the lowest number of alleles was observed at the loci of DCA15 and UDO9 as 5, respectively.

Previous studies conducted on olive cultivars in different olive growing countries also revealed high polymorphism by using SSR markers and DCA9 primer was found more discriminative for olive, that support the current findings as well (Bandelj et al., 2002; Poljuha et al., 2008; Alba et al., 2009;
Table 2. Simple sequence repeats (SSRs), number of detected alleles, observed heterozygosity $(\mathrm{Ho})$ and expected heterozygosity $(\mathrm{He})$ of 10 SSR markers on thirty olive genotypes and four cultivars

\begin{tabular}{cccc}
$\begin{array}{c}\text { SSR } \\
\text { Primers }\end{array}$ & $\begin{array}{c}\text { Number of } \\
\text { alleles }\end{array}$ & $\begin{array}{c}\text { Expected } \\
\text { heterozygosity } \\
(\mathrm{He})\end{array}$ & $\begin{array}{c}\text { Observed } \\
\text { heterozygosity } \\
(\mathrm{Ho})\end{array}$ \\
\hline DCA15 & 5 & 0.474 & 0.529 \\
DCA18 & 10 & 0.844 & 0.676 \\
UDO12 & 6 & 0.650 & 0.500 \\
UDO24 & 7 & 0.767 & 0.523 \\
UDO4 & 6 & 0.547 & 0.494 \\
UDO9 & 5 & 0.333 & 0.323 \\
DCA11 & 12 & 0.841 & 0.529 \\
DCA9 & 14 & 0.874 & 0.764 \\
UDO22 & 8 & 0.526 & 0.676 \\
UDO11 & 6 & 0.780 & 0.535 \\
Total & 79 & 6.636 & 5.549 \\
Average & 7.9 & 0.663 & 0.554 \\
\hline
\end{tabular}

Abdessemed et al., 2015). Noormohammadi et al. (2009) and Muzzalupo et al. (2014) also found high polymorphism in olive cultivars with DCA9 marker.

The number of average polymorphic alleles per primers was 7.9 thus comparable with the results of Cipriani et al. (2002), Poljuha et al. (2008), Alba et al. (2009) and Roubos et al. (2010), but lower than data published by Lopes et al. (2004) and Abdessemed et al. (2015). The contrary results of the 
560

Table 3. Allele size of the olive genotypes and cultivars under study

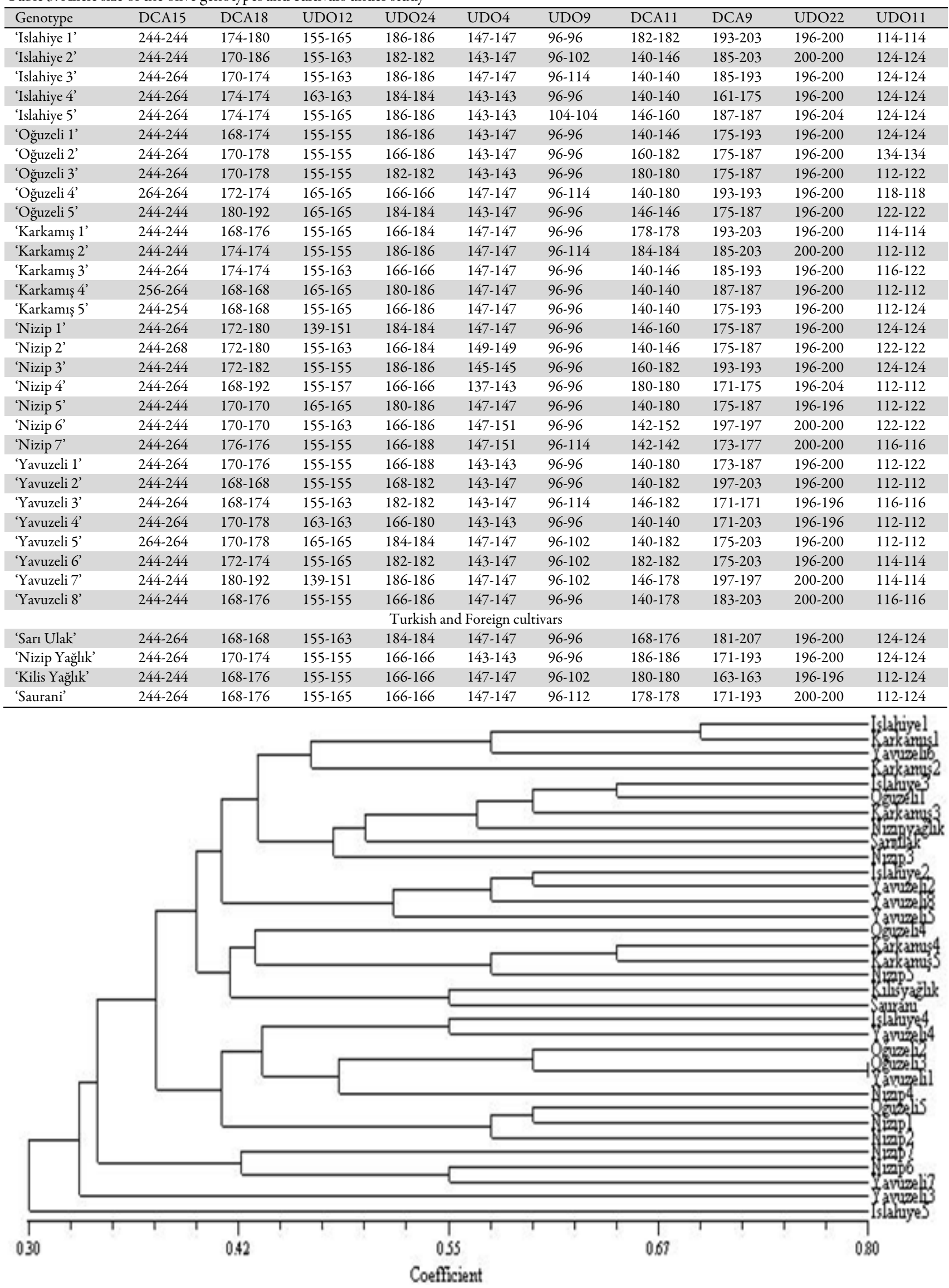

Fig. 1. The UPGMA dendrogram based on 10 SSR markers, illustrating the relative similarity among thirty olive genotypes and four cultivars from Turkey and Syria 
molecular marker researches on olive might result from the different genetic bases of the accessions tested, primer numbers, types of molecular marker, higher number of analyzed samples, as well as due to the more diverse genotypes analyzed.

The value of observed heterozygosity $(\mathrm{Ho})$ was less than the value of expected heterozygosity $(\mathrm{He})$ for all SSR loci, except DCA15 and UDO22. UDO9 loci revealed the lowest expected heterozygosity $(\mathrm{He})$ as 0.333 , while the loci DCA9 gave the highest expected heterozygosity value as 0.874 . Observed heterozygosity $(\mathrm{Ho})$ was the highest in DCA9 loci as 0.764 , while the lowest, as 0.323 , was noted in UDO9 loci (Table 2). The results indicate that the studied population may exhibit a high level of inbreeding within isolated and closely related individuals. Muzzalupo et al. (2014) reported higher expected heterozygosity among 489 olive cultivars by using 11 nuclear SSR markers.

Based on SSR profiles of the thirty Gaziantep genotypes as well the data for the one foreign and the three Turkish cultivars, nu synonyms were observed neither among Turkish cultivars or foreign ones and neither synonym were determined between the two group of genotypes.

Allele size varied from $96 \mathrm{bp}$ to $268 \mathrm{bp}$ and the most frequent alleles were $96 \mathrm{bp}(16.17 \%)$, followed by $244 \mathrm{bp}$ (13.23\%), 147 bp (12.05\%), 155 bp (10.58\%), 200 bp (10.29\%) and 196 bp (9.11\%), respectively (Table 3).

The most closely related genotypes were 'Oğuzeli 3' and 'Yavuzeli 1' with 0.80 similarity ratio. The most genetically divergent cultivars were 'Yavuzeli 6' and 'Kilis Yağlik' (0.30), 'Yavuzeli 6' and 'Saurani' (0.20), 'Nizip 7' and 'Yavuzeli 4' (0.15), 'Islahiye 5' and 'Nizip Yağlık' (0.10), indicating a fairly big range, thus signifying that the olive genotypes and cultivars tested showed some diverse relationships.

UPGMA cluster analysis of the 34 olive genotypes and cultivars using the 10 polymorphic SSR markers resulted in the dendrogram shown in Fig. 1, which displayed a good fit to the genetic similarity matrix. Five groups could be distinguished by truncating the dendrogram and local genotypes 'Islahiye 5' and 'Yavuzeli 3' was clustered in a solitary group (Group I and Group II). Group III included 3 local genotypes, namely 'Yavuzeli 7', 'Nizip 7' and 'Nizip 6. The Group IV also include 9 local genotypes and was further divided 2 sub-groups. The first subgroups included local 'Nizip 2', 'Nizip 1' and 'Oguzeli 5 ' genotypes, while subgroup 2 included 'Nizip 4', 'Yavuzeli 1', 'Oguzeli 3', 'Oguzeli 2', 'Islahiye 4' and 'Yavuzeli 4' (Fig. 1). 'Yavuzeli 1' and 'Oguzeli 3' were the closest genotypes, with a similarity coefficient of 0.80 (Fig. 1). Group V contained the rest of 20 genotypes and cultivars. The standard Turkish cultivars 'Nizip Yaglik' and 'Kilis Yaglik' and also the Syrian cultivar 'Saurani' were placed together within Group V. 'Saurani' and 'Kilis Yaglik' showed 0.55 similarity coefficient. Group $\mathrm{V}$ was further clustered into 4 major subgroups containing 6, 4, 6 and 4 genotypes/cultivars.

As expected, the most closely related cultivars were within each gene pool. A partly clustering was observed among cultivars from two gene pools, suggesting that Turkish and foreign olive cultivars continue to be related. These results also indicated that grouping genotypes based on the geographic origin is not useful in olive. Besnard et al. (2001) found that olive genotypes from different countries clustered together within a group and they did not find any grouping pattern based on their geographical origins. The result was similar to that of Poljuha et al. (2008) who studied genetic diversity among Slovenian and Croatian olive cultivars and found that Croatian olive cultivars clustered with olive cultivars from Slovenia. Previous studies indicated that olive genotypes have been freely exchanged among collectors in different countries for centuries.

\section{Conclusions}

In conclusion, the SSR analysis was found to be useful for the detection of genetic differences among the olive accessions. The genetic relationships among olive cultivars may facilitate the selection of genitors in various breeding programs with the hypothesis that the more genetically diverse the parents, the more likely they are to possess unique alleles for traits of interest for their descendants. This study will help to restructure the Turkish olive cultivar database, to widen the genetic base and give the premises to introduce new varieties.

\section{References}

Abdessemed S, Muzzalupo I, Benbouza H (2015). Assessment of genetic diversity among Algerian olive (Olea europaea L.) cultivars using SSR marker. Scientia Horticulturae 192:10-20.

Alba V, Montemurro C, Sabetta W, Pasqualone A, Blanco A (2009). SSRbased identification key of cultivars of Olea europaea L. diffused in Southern Italy. Scientia Horticulturae 123:11-16.

Aparicio R, Harwood J (2013). Handbook of olive oil. Analysis and properties. 2nd ed Springer, New York.

Bandelj D, Jakse J, Javornik B (2002). DNA fingerprinting of olive varieties by microsatellite markers. Food Technology and Biotechnology 40(3):185-190.

Besnard G, Baradat P, Berville A (2001). Genetic relationships in the olive (Olea europaea L.) reflect multilocal selection of cultivars. Theoretical and Applied Genetics 102:251-258.

Belaj A, Satovic Z, Cipriani G, Baldoni L, Testolin R, Rallo L, Trujillo I (2003). Comparative study of the discriminating capacity of RAPD, AFLP and SSR markers and their effectiveness in establishing genetic relationships in olive. Theoretical and Applied Genetics 107:736-744.

Besnard G, Henry P, Wille L, Cooke D, Chapuis E (2007). On the origin of the invasive olives (Olea europaea L.). Heredity 99:608-619.

Boskou D (2009). Olive oil minor constituents and health. In: Boskou D (Ed). Culinary. applications of olive oil-minor constituents and cooking. Taylor \& Francis Group, LLC, Philadelphiapp 1-7.

Bowcock AM, Ruiz-Linares A, Tomfohrde T, Minch E, Kidd JR, CavalliSforza LL (1994). High resolution of human evolutionary trees with polymorphic microsatellites. Nature 368:455-457.

Cipriani G, Marrazzo MT, Marconi R, Cimato A, Testolin R (2002). Microsatellite markers isolated in olive (Olea europaea $\mathrm{L}$.) are suitable for individual fingerprinting and reveal polymorphism within ancient cultivars. Theoretical and Applied Genetics 104:223-228.

Ercisli S, Ipek A, Barut E (2011). SSR marker-based DNA fingerprinting and cultivar identification of olives (Olea europaea L.). Biochemical Genetics 49(9-10):555-561.

FAO (2014). Agricultural Statistics of the Food and Agriculture Organization of the United Nations, Rome. Retrieved 2016 June 11 from www.fao.org. 
562

IOOC (2015). International Olive Oil Council. Retrieved 2016 June 7 from http://www.internationaloliveoil.org/noticias.

Ipek A, Barut E, Gulen H, Ipek M (2012). Assessment of inter-and intracultivar variations in olive using SSR markers. Scientia Agricola 69(5):327-335.

Kaczmarska E, Gawronski J, Dyduch-Sieminska M, Najda A, Marecki W, Zebrowska J (2015). Genetic diversity and chemical characterization of selected Polish and Russian cultivars and clones of blue honeysuckle (Lonicera caerulea). Turkish Journal of Agriculture and Forestry 39:394 402.

Khakwani AA, Shiraishi M, Zubair M, Baloch MS, Naveed K, Awan I (2005). Effect of seedling age and water depth on morphological and physiological aspects of transplanted rice under high temperature. Journal ofZhejiang University Science B6:389-395.

Kole C (2011). Wild crop relatives: Genomic and breeding resources: Temperate fruits. Springer, New York.

Lopes MS, Mendonca D, Sefc KM, Sabino Gil F, da Camara Machado A (2004). Genetic evidence of intra-cultivar variability within Iberian olive cultivars. HortScience 39:1562-1565.

Lumaret R, OuazzaniN, Michaud H, Vivier G, Deguilloux MF, Giusto FD (2004). Allozyme variation of oleaster populations (wild olive tree) (Olea europaea L.) in the Mediterranean Basin. Heredity 92:343-351.

Minch E, Ruiz-Linares A, Goldstein DB, Feldman M, Cavalli-Sforza LL (1995). Microsat (Version 1.4d): a computer program for calculating various statistics on microsatellite allele data. Stanford University Medical Center,Stanford.

Montemurro C, Pasqualone A, Simeone R, Sabetta W, Blanco A (2008). AFLP molecular markers to identify virgin olive oils from single Italian cultivars. European Food Research and Technology 226:1439-1444.

Muzzalupo I, Vendramin GG, Chiappetta A (2014). Genetic biodiversity of Italian olives (Olea europaea) germplasm analyzed by SSR markers. The Scientific WorldJournal Article ID 296590.
Navero DB, Cimato A, Fiorino P, Romero LR, Touzani A, Castaneda C, Serafini F, Navas IT (2000). World catalogue of olive varieties (1st ed.). Madrid, Spain: International Olive Oil Council.

Nemli S, Kianoosh T, Tanyolaç MD (2015). Genetic diversity and population structure of common bean (Phaseolus vulgaris L.) accessions through retrotransposon-based interprimer binding sites (iPBSs) markers. Turkish Journal of Agriculture and Forestry 39:940-948.

Noormohammadi Z, Hosseini-Mazinani M, Trujillo I, Belaj A (2009). Study of intracultivar variation among main Iranian olive cultivars using SSR markers. Acta BiologicaSzegediensis 53(1):27-32.

Paetkau D, Calvert W, Stirling I, Strobeck C (1995). Microsatellite analysis of population structure in Canadian polar bears. Molecular Ecology 4:347-354.

Poljuha D, Sladonja B, Setic E, Milotic A, Bandelj D, Jakse J, Javornik B (2008). DNA fingerprinting of olive varieties in Istria (Croatia) by microsatellite markers. Scientia Horticulturae 115:223-230.

RohlfFJ (2004). NTSYS-pc numerical taxonomy and multivariate analysis system. Version 2.11V. Exeter software, Setauket, New York.

Roubos K, Moustakas M, Aravanopoulos FA (2010). Molecular identification of Greek olive (Olea europaea) cultivars based on microsatellite loci. Genetics and Molecular Research 9(3):1865-1876.

Sarri V, Baldoni L, Porceddu A, Cultrera NGM, Contento A, Frediani M, Belaj A, Trujillo I, Cionini PG (2006). Microsatellite markers are powerful tools for discriminating among olive cultivars and assigning them togeographically defined populations. Genome 49:1606-1615.

Sesli M, Yegenoglu ED (2010). Genetic relationships among and within wild and cultivated olives based on RAPDs. Genetics and Molecular Research 9(3):1550-1556.

Sneath PHA, Sokal RR (1973). Numerical taxonomy: the principles and practice of numerical classification. Freeman, San Francisco.

Taamalli W, Geuna F, Banfi R, Bassi D, Daoud D, Zarrouk M (2006). Agronomic and molecular analyses for the characterization of accessions in Tunisian olive germplasm collections. Electronic Journal of Biotechnology 9(5):467-481. 